\title{
Dismal Science: Chaucer and Gower on Alchemy and Economy
}

Robert Epstein Dr.

repstein@fairfield.edu

Follow this and additional works at: https://digitalcommons.fairfield.edu/english-facultypubs

Copyright 2014 Johns Hopkins University Press

The author post-print has been archived here with permission from the copyright holder.

\section{Peer Reviewed}

\section{Repository Citation}

Epstein, Robert Dr., "Dismal Science: Chaucer and Gower on Alchemy and Economy" (2014). English

Faculty Publications. 121.

https://digitalcommons.fairfield.edu/english-facultypubs/121

\section{Published Citation}

Epstein, Robert. "Dismal Science: Chaucer and Gower on Alchemy and Economy." Studies in the Age of Chaucer 36.1 (2014): 209-248. doi:10.1353/sac.2014.0002.

This item has been accepted for inclusion in DigitalCommons@Fairfield by an authorized administrator of DigitalCommons@Fairfield. It is brought to you by DigitalCommons@Fairfield with permission from the rightsholder(s) and is protected by copyright and/or related rights. You are free to use this item in any way that is permitted by the copyright and related rights legislation that applies to your use. For other uses, you need to obtain permission from the rights-holder(s) directly, unless additional rights are indicated by a Creative Commons license in the record and/or on the work itself. For more information, please contact digitalcommons@fairfield.edu. 


\section{Dismal Science:}

\section{Chaucer and Gower on Alchemy and Economy}

Alchemy holds a fascination for modern times, as the forerunner of chemistry and perhaps the precursor of modern science, as a lore of the occult, or as a model for alternative spiritual or psychological systems. ${ }^{1}$ But alchemy is most often invoked as a

\footnotetext{
${ }^{1}$ The literature on the history of alchemy and its relation to the rise of science is voluminous; some notable contributions include: Frances A. Yates, Giordano Bruno and the Hermetic Tradition (Chicago: University of Chicago Press, 1964); Robert P. Multhauf, The Origins of Chemistry (London: Oldbourne, 1966); Allen G. Debus, The Chemical Philosophy: Paracelsian Science and Medicine in the Sixteenth and
} Seventeenth Centuries (New York: Science History Publications, 1977); Betty Jo Teeter Dobbs, The Janus Face of Genius: The Role of Alchemy in Newton's Thought (Cambridge: Cambridge University Press, 1991); William R. Newman and Lawrence M. Principe, Alchemy Tried in the Fire: Starkey, Boyle, and the Fate of Helmontian Chymistry (Chicago: University of Chicago Press, 2002). On the current standing of alchemy in the history of science, see two recent assessments: Lawrence M. Principe, “Alchemy Restored," Isis 102 (2011): 305-312; William R. Newman, "What Have We Learned from the Recent Historiography of Alchemy?” Isis 102 (2011): 313-321. Principe and Newman critique the ahistorical nature of much nineteenth- and twentieth- 
metaphor, usually in one of two ways. It can stand for a mysterious and magical process, or it can serve as an emblem of deliberately deceptive hokum. In particular, it functions as a metaphor for the perpetually abstruse processes of the commercial economy. For Marx, alchemy is the master trope for the inexorable power of capitalism to convert all things into commodities: "Not even are the bones of saints, and still less are more delicate res sacrosanctae, extra commercium hominum able to withstand this alchemy." 2 On the other hand, George Soros, one of the most successful private financiers in history, entitled his first book The Alchemy of Finance. ${ }^{3}$ And the recent book by the economics century occult and mystical reception of alchemy in "Some Problems with the Historiography of Alchemy," in Secrets of Nature: Astrology and Alchemy in Early Modern Europe, edited by William R. Newman and Anthony Grafton (Cambridge, MA: MIT Press, 2001), pp. 385-431.

${ }^{2}$ Karl Marx, Capital: A Critical Analysis of Capitalist Production, trans. Samuel Moore and Edward Aveling (Moscow: Progress Publishers, 1965), Volume 1, p. 132. Marx also uses alchemy as a metaphor for the fraud underlying capitalist accumulation; he says of a colonial governor in India, "His favorites received contracts under conditions whereby they, cleverer than the alchemists, made gold out of nothing" (704). On alchemical language and thought in Marx, see Karen Pinkus, Alchemical Mercury: A Theory of Ambivalence (Stanford: Stanford University Press, 2010), particularly Chapter 6, “Reading Capital I Alchemically,” pp. 141-157.

${ }^{3}$ George Soros, The Alchemy of Finance: Reading the Mind of the Market (New York: John Wiley \& Sons, 1994). Soros does not use the metaphor of alchemy casually, and he does not employ it as a shorthand for occult wisdom. Rather, he sees alchemy as 
columnist Neil Irwin about the central bankers who used every legal and fiduciary means at their disposal to address the global financial crisis of 2008 is called The Alchemists. ${ }^{4}$ Then there are the comments of Larry Summers, economic advisor to President Obama, on Mitt Romney's budget plan during the 2012 United States presidential election: “This is alchemy... Lead cannot be turned into gold. Two plus two cannot equal five... And 20 percent across-the-board tax cuts cannot be squared with balanced budgets without raising middle-class taxes or eviscerating government." Alchemy is that which is obscure in its operation, but somehow works; it is also that which seems to work, but does not.

In the late Middle Ages, alchemy's social position was shifting and uncertain. It had an ancient lineage and an extensive written tradition, but it was never incorporated into the standard curricula of schools or universities; it was variously condemned and endorsed by scholarly authorities; its practitioners were notorious in popular imagination

analogous to market analysis in that it is practical without being scientific or even entirely rational: "Scientific theories are judged by the facts; financial decisions are judged by the distorted views of the participants. Instead of scientific method, financial markets embody the method of alchemy" (304).

${ }^{4}$ Neil Irwin, The Alchemists: Three Central Bankers and a World on Fire (New York: Penguin, 2013).

${ }^{5}$ Bonnie Kavoussi, "Larry Summers: Mitt Romney’s Budget Plan is 'Alchemy," The Huffington Post, October 23, 2012, http://www.huffingtonpost.com/2012/10/23/larrysummers-mitt-romney_n_2005026.html. 
for delusion and chicanery, but they could also be patronized by courts and princes. ${ }^{6}$ Alchemy and alchemists appear only occasionally in medieval literature, but the art figures at significant points in the two great tale collections of fourteenth-century England. ${ }^{7}$ John Gower praises it in the fourth book of Confessio Amantis. Chaucer, after a number of pejorative asides, abruptly and belatedly introduces alchemy into the Canterbury Tales and then debunks it at considerable length in the Canon's Yeoman's Prologue and Tale.

Critics attempting to explain such literary uses of alchemy have frequently and rightly taken it as metaphorical for economic operation. But the medieval authors understood neither alchemy nor economics in the same manner that later writers would. Like moderns, Gower and Chaucer saw in alchemy analogies to the commercial economy. But unlike most modern thinkers, Gower and Chaucer interpreted alchemy as an inverted analogy, seeing its processes as opposite to the workings of economic forces. The poets' very different depictions of alchemy and alchemists therefore reveal the profound contrasts in their views of money and economy.

\footnotetext{
${ }^{6}$ See Will H. L. Ogrinc, "Western Society and Alchemy from 1200 to 1500,” Journal of Medieval History 6 (1980): 103-32; William R. Newman and Anthony Grafton, "Introduction: The Problematic Status of Astrology and Alchemy in Premodern Europe," in Newman and Grafton, eds., Secrets of Nature, pp. 1-38.

${ }^{7}$ Of course, alchemy has its own literature, including alchemical poetry. See the two-part article by Didier Kahn, “Alchemical Poetry in Medieval and Early Modern Europe: Part I-Preliminary Survey," Ambix 57 (2010): 249-74, and “Part II-Synthesis," Ambix 58
} (2011): 62-77. 


\section{Gower: "The science of himself is trewe"}

Two thirds of the way through Book 4 of Confessio Amantis, Genius chooses to counterbalance his indictment of Sloth with some praise of its opposite, industriousness. What follows is a catalogue of various fields of liberal arts, natural philosophy, and technology, from poetry, music, painting, and sculpture, to fishing, metallurgy, textiles, augury, and cuisine. For each of these Gower identifies, though sometimes rather idiosyncratically and obscurely, the legendary or mythical founder of the discipline. But at one point, Gower expounds, at much greater length, on

thilke experience,

Which cleped is alconomie

Wherof the selver multeplie

Thei made and ek the gold also. $[4.2458-61]^{8}$

“Alconomie," according to Gower, posits seven material elements, each associated with a planet. These elements exist in a continuum, running from gold at one extreme to silver at the other:

For as the philosphre tolde

Of gold and selver, thei ben holde

Tuo principal extremites

To whiche alle othre be degres

Of the metalls ben accordant... [4.2487-91]

\footnotetext{
${ }^{8}$ All quotations of Confessio Amantis are taken from the edition of Russell A. Peck, vols. 1-3 (Kalamazoo, MI: Medieval Institute Publications, 2000-2004).
} 
There are, Gower says, three "philosophers' stones." The first two are the lapis vegetabilis, which has the power "to kepe and to preserve / The bodi fro siknesses alle / Til deth of kinde upon him falle" (4.2538-40), and the lapis animalis, which is able to heighten and maintain the five senses, "wherof a man mai hiere and se / And smelle and taste in his degré, / And for to fiele" (4.2545-47). ${ }^{9}$ It is the third stone, the mineral stone, that has the power to refine any metal, removing any impurities (4.2555-56). ${ }^{10}$ Since gold and silver are the purest extremes in the continuum of metals,

This mineral, so as I finde, Transformeth al the ferste kynde And makth hem able to conceive Thurgh his vertu, and to receive Both in substance and in figure Of gold and selver the nature. [4.2559-64] This increase of gold, Gower acknowledges, is the ultimate goal of alchemy and alchemists: "For to the rede and to the whyte" — standard alchemical figures for gold and

\footnotetext{
${ }^{9}$ On Gower's alchemical philosophy, see George Fox, The Mediaeval Sciences in the Works of John Gower (1931; reprint New York: Haskell House, 1966), pp. 114-135. ${ }^{10}$ Gower seems to equate the "mineral stone" and the "elixir"; in other sources, the elixir is a substance made from the philosophers' stone and used for transmutation. The three distinct stones seem to be unique to Gower; they may derive from Gower's misinterpretation of passages in other sources describing categories of materials used to create the philosophers' stone. See Fox, Mediaeval Sciences, pp. 127-28.
} 
silver_ “"This ston hath pouer to profite. / It makth multiplicacioun / Of gold" (4.257174).

Gower, like many medieval writers, credits Hermes Trismegistus with the founding of alchemy. Gower also cites Geber, Ortolan, Morien, and Avicenna as authorities on the craft. Gower's own sources seem to have included Vincent of Beauvais, Arnaldus of Villanova, Roger Bacon, the Libellus de Alchimia ascribed to Albertus Magnus, and other widely circulated texts. ${ }^{11}$ Gower's descriptions of alchemy, therefore, could be called, as they often have been, conventional-but for the fact that there were competing conventions.

Gower was approaching alchemy at an unstable period in its history. The craft was introduced to Europe via Arabic texts in the twelfth century and would flourish in the Early Modern period, but in the thirteenth century alchemy had become a point of intellectual controversy. ${ }^{12}$ Thirteenth-century authorities, notably Albertus Magnus, wrote generally favorably of alchemy, and Roger Bacon defended it vigorously. But other scholastics, including Giles of Rome, expressed reservations about the value of its supposed productions, and a Latin translation of an Arabic anti-alchemical text was

${ }^{11}$ See Fox, Mediaeval Sciences, and Peck's note to Confessio 4.2468-78.

${ }^{12}$ See Lawrence M. Principe, The Secrets of Alchemy (Chicago: University of Chicago Press, 2013), pp. 51-82. See also Ogrinc, “Western Society,” pp. 104-107; Multhauf, Origins of Chemistry, pp. 143-200; Debus, Chemical Philosophy, pp. 11-14. 
widely received as the work of Albert. ${ }^{13}$ After convening a debate on the issue, Pope John XXII condemned the practices of alchemists in a decretal in 1317, declaring, "Poor themselves, the alchemists promise riches which are not forthcoming; wise also in their own conceit, they fall into the ditch which they themselves have digged." 14 In the fifteenth century several European countries would ban the practice of alchemical transmutation; Henry IV of England passed such a decree in $1404 .{ }^{15}$

Poets of the thirteenth and fourteenth centuries varied in their representations of alchemy. Jean de Meun, in his discussion of the powers of Art and Nature, says that Art "may learn enough alchemy to be able to colour every metal, but she would kill herself before she could transmute the species, unless she first reduced them to their elemental

${ }^{13}$ See William R. Newman, Promethean Ambitions: Alchemy and the Quest to Perfect Nature (Chicago: University of Chicago Press, 2004), pp. 43-54. See also Principe, The Secrets of Alchemy, pp. 58-62.

${ }^{14}$ Quoted in Edgar H. Duncan, “The Literature of Alchemy and Chaucer’s Canon’s Yeoman's Tale: Framework, Theme, and Characters," Speculum 43 (1968): 633-56 (636). See also Principe, Secrets of Alchemy, p. 61; J. R. Partington, “Albertus Magnus on Alchemy," Ambix 1 (1937): 3-20. The Latin text of the decretal is printed in Sources and Analogues of Chaucer's "Canterbury Tales," edited by W. F. Bryan and Germaine Dempster (New York: Humanities Press, 1958 (1941)), pp. 691-92.

${ }^{15}$ Principe, Secrets of Alchemy, p. 62. Petitioners were occasionally granted license to practice alchemy; the ban was ultimately lifted in 1689. See Duncan, "Literature of Alchemy,” p. 634; D. Geoghagen, “A License of Henry VI to Practise Alchemy,” Ambix 6 (1957): 10-17. 
matter; if she worked all her life she would never catch up with Nature." But he then adds, "It is worthy of note, nevertheless, that alchemy is true art, and that anyone who worked at it seriously would discover great marvels."16 Petrarch, in Remedies for Prosperity, addresses alchemy in a dialogue of Hope and Reason:

HOPE: I hope for good results with alchemy.

REASON: It is surprising that you hope for something which never happened to you or anyone else. All reports that it happened to some are fabricated by people who have found it expedient to believe so...

HOPE: The alchemist promises me great things.

REASON: Tell him to perform for himself what he promises to others, and to cure his own poverty first. Alchemists are an indigent lot who admit that they are paupers but wish to enrich others as though the poverty of others were more troublesome to them than their own. Wretched themselves, they protest impudently that they take pity on others and promise great things, sometimes even to people they do not know at all. O what rotten promises, what stupid credulity! ${ }^{17}$

${ }^{16}$ The Romance of the Rose, trans. and ed. Frances Horgan (Oxford: Oxford University Press, 1994), pp. 248-49. On Jean de Meun's treatment of alchemy, see Newman, Promethean Ambitions, pp. 77-82.

${ }^{17}$ Conrad H. Rawski, Petrarch's Remedies for Fortune Fair and Foul: A Modern English Translation of De remediis utriusque Fortune, with a Commentary, Volume 1 (Bloomington: Indiana University Press, 1991), pp. 299-300. 
In Gower's England, Langland apparently harbors the popular suspicion that alchemy is a form of dark magic. In Piers Plowman, Dame Study warns Will against those sciences that are mere "fybicches" (tricks) that she invented solely to mislead human minds:

Yut are thre fybicches of forels of manye mannys wittes,

Of experimens of alkonomye, of Albertes makyng,

Nigramauncie and permancie, the pouke to reyse;

Yif thou thinke Dowel, del therwith nevere.

Al these sciences, sikerly, I myself founded-

Founded hem formest folk to deseyven. ${ }^{18}$

Gower, therefore, has no single, conventional path when approaching alchemy.

He chooses to praise it at length. He does ultimately declare that the contemporary practice is unwise and that those who pursue the alchemy are unlikely to be able to duplicate the successes of the ancient practitioners, making it essentially a lost art:

Bot now it staunt al otherwise;

Thei speken faste of thilke ston,

Bot hou to make it, nou wot non

After the sothe experience.

And natheles get diligence

Thei setten upon thilke dede,

${ }^{18}$ Piers Plowman: The A Version, edited by Míceál F. Vaughan (Baltimore: Johns Hopkins University Press, 2011), XI.161-66. Compare B Version, X.212-21. Piers Plowman: The B Version, edited by George Kane and E. Talbot Donaldson (Berkeley: University of California Press, 1988). 
And spille more than thei spede;

For allewey thei finde a lette,

Which bringeth in poverte and dette

To hem that riche were afore.

The lost is had, the lucre is lore,

To gete a pound thei spenden fyve;

I not hou such a craft schal thryve

In the manere as it is used:

It were betre be refused

Than for to worchen upon weene

In thing which stant noght as thei weene. [4.2580-96]

Yet Gower is acknowledging that alchemy is at heart a "sothe experience"-empirical fact — and he is at pains to insist that alchemical theory and its lore are natural, authoritative, and genuine:

For thei be whom this art was founde

To every point a certain bounde

Ordeignen, that a man mai finde

This craft is wroght be weie of kinde,

So that ther is no fallas inne. [4.2505-09]

What makes this curious is that Gower uncharacteristically ignores the moral questions that haunted alchemy in the late Middle Ages. Contemporary authorities did not merely question whether some practicing alchemists were charlatans or fools. They 
also expressed reservations about what alchemy actually achieved when it was successful and the moral and social ramifications of the art.

The concern of intellectual critics in Gower's time was not so much that alchemists were unable to perform the functions they claimed, but that alchemy, if efficacious, might be false and misleading. As William Newman has explained, the debate hinged on a perceived conflict between Art and Nature - the question of whether any product of human artifice could equal, or even improve, received creation, a question ultimately of profound importance to humanistic thought and to conceptions of science and technology. ${ }^{19}$ A point of debate among scholastics like Albert Magnus and Giles of Rome was whether the precious metals produced by alchemists were true gold and silver or synthetic and therefore artificial gold and silver, differing in some fundamental (though perhaps imperceptible) way from the real metals. ${ }^{20}$ As Aquinas comments:

Gold and silver are costly not only on account of the usefulness of the vessels and other like things made from them, but also on account of the excellence and purity of their substance. Hence if the gold or silver produced by alchemists has not the true specific nature of gold and silver, the sale thereof is fraudulent and unjust, especially as real gold and silver can produce certain results by their natural action, which the counterfeit gold and silver of alchemists cannot produce... If however real gold were to be produced by alchemy, it would not be unlawful to sell it for the genuine article, for nothing prevents art from employing certain

\footnotetext{
${ }^{19}$ See Newman, "Alchemy and the Art-Nature Debate," in Promethean Ambitions, pp.
} 34-114.

${ }^{20}$ Ibid., pp. 51-54. 
natural causes for the production of natural and true effects, as Augustine says... of things produced by the art of the demons. ${ }^{21}$

In either case, critics saw economic implications in the validity of the precious metals that secured the value of currency. If alchemical gold was false, it could force true gold out of the marketplace, destabilizing the value of currency; if alchemists were to produce true gold in significant quantities, it could potentially devalue currency by deflating the value of gold. ${ }^{22}$ Alchemists, therefore, could be seen as a kind of counterfeiters. In his decretal, Pope John XXII declares that "though there is no such thing in nature, they pretend to make genuine gold and silver by a sophistic transmutation; to such an extent does their damned and damnable temerity go that they stamp upon the base metal the characters of public money for believing eyes." 23

It is for these reasons that Dante confines alchemists in one of the deepest portions of Hell, the tenth and final bolgia of the eighth circle, "where the ministress of the High Lord, infallible Justice, punishes the falsifiers" (XXIX.55-57). ${ }^{24}$ Here, where

\section{${ }^{21}$ Saint Thomas Aquinas, Summa Theologica: Translated by Fathers of the English} Dominican Province (New York: Benziger Brothers, 1947-48), p. 4701.

${ }^{22}$ See Principe, Secrets of Alchemy, pp. 59-60. See also Newman, Promethean Ambitions, p. 131.

${ }^{23}$ Duncan, "The Literature of Alchemy," p. 637. See also Principe, Secrets of Alchemy, p. 61 .

${ }^{24}$ Dante Alighieri, The Divine Comedy: Inferno, trans. Charles S. Singleton (Princeton: Princeton University Press, 1970). It is worth noting that Dante and Virgil left the 
the air is poisoned with contagion and there are "spirits languishing in divers heaps" (XXIX.66), Dante encounters two souls. The first says that he was executed by Albero of Siena for falsely claiming that he could teach him to fly, adding, "But, for the alchemy I practiced in the world, Minos, to whom it is not allowed to err, condemned me to this last pouch of the ten" (XXIX.118-20). The second points even more explicitly to the deceitful art of alchemy: "I am the shade of Capocchio, who falsified the metals by alchemy; and you must recall, if I rightly eye you, how good an ape of nature I was" (XXIX.136-39).

Note that Dante is not condemning alchemists for falsely claiming to be able to transmute metals. Rather, Dante's alchemists are languishing at the bottom of the eighth circle because the precious metals that they transform other metals into are not the true gold and silver that they seem to be, and this makes them a species of falsifiers or counterfeiters.

And yet Gower, normally as concerned as Dante with adjudging and critiquing the moral status of individuals and classes, has only praise for alchemy's inventors and original practitioners. Gower emphasizes the truth and indeed the virtue of the craft:

Bot noght forthi, who that it knewe,

The science of himself is trewe

Upon the forme as it was founded,

Wherof the names yit ben grounded

Of hem that ferste it founden oute;

And thus the fame goth aboute

usurers sitting on burning sands back in the seventh circle, with sinners against natureplenty deep, but not nearly so deep as falsifiers like the alchemists. 
To suche as soghten besinesse

Of vertu and of worthinesse. [4.2597-2604]

It is perhaps not so surprising that in a section devoted to disciplines of science and learning Gower chooses the side of human artifice in a debate between art and nature. But what makes his defense of the empirical and moral validity of alchemy particularly puzzling is its position within the Confessio. This section, late in Book 4, comes just before the mammoth Book 5, and its extended critique not just of the sin of avarice but specifically of commerce and money.

Gower's economic critique derives ultimately from Aristotle's Politics. In the Nicomachean Ethics, Aristotle studies the power of money to create equivalencies. It facilitates the exchange of goods, even goods of widely disparate natures and values. It also provides a way of finding equivalent values of abstract concepts, such as labor and time. "It measures all things," he says. ${ }^{25}$ It is obvious, Aristotle insists, that exchange took place before there was money. Money simply facilitates exchange: "Money, then, acting as a measure, makes goods commensurate and equates them."26

In the Politics, on the other hand, Aristotle makes a distinction between the art of getting wealth and "household management" (literally, economics). ${ }^{27}$ Barter, the kind of

\footnotetext{
${ }^{25}$ An Introduction to Aristotle, ed. Richard McKeon (New York: Modern Library, 1947), p. 409. ${ }^{26}$ Ibid., p. 410.

${ }^{27}$ A particularly valuable review of Aristotelian economic thought and its medieval reception is provided by Lianna Farber in An Anatomy of Trade in Medieval Writing:
} 
exchange that he says in the Ethics has always existed, entails the exchange of "the necessities of life and nothing more." But, he goes on, "When the use of coin had once been discovered, out of the barter of necessary articles arose the other art of wealthgetting, namely, retail trade." 28 So, there is the good and appropriate getting of wealth, the acquisition of the commodities needed for the proper maintenance of the household; and there is the art of accumulating wealth through money and trade. This other art of wealth-getting is unnecessary and undesirable. It is, Aristotle says, "unnatural," here in the sense of being against the natural order. It is not a "natural part of the management of the household." 29 Money is an instrument for the measure of value; it has no value in and of itself because it has no use except as a method of measure. Money is therefore not useful as a commodity, so there is no natural benefit to its accumulation. And as it lends itself to pure accumulation, the search for monetary profit knows no natural limits: there is no point at which one could be said to have enough. In fact, it is simply "a mode by which men gain from one another," and it is therefore a mode of exploitation culminating in usury. ${ }^{30}$ And all of this is true not generally of gold or wealth or property but specifically of coined money:

Originating in the use of coin, the art of getting wealth is generally thought to be concerned with it and to be the art which produces riches and wealth;

Value, Consent, and Community (Ithaca: Cornell University Press, 2006); see especially pp. 12-37.

${ }^{28}$ Aristotle, p. 568.

${ }^{29}$ Ibid., p. 570.

${ }^{30}$ Ibid., p. 571. 
having to consider how they may be accumulated. Indeed, riches is assumed by many to be only a quantity of coin, because the arts of getting wealth and retail trade are concerned with coin. Others maintain that coined money is a mere sham, a thing not natural, but conventional only, because, if the users substitute another commodity for it, it is worthless, and because it is not useful as means to any of the necessities of life, and, indeed, he who is rich in coin may often be in want of necessary food. But how can that be wealth of which a man may have a great abundance and yet parish with hunger, like Midas in the fable, whose insatiable prayer turned everything that was set before him into gold? Hence men seek after a better notion of riches and of the art of getting wealth than the mere acquisition of coin, and they are right. ${ }^{31}$

These two Aristotelian positions are not necessarily irreconcilable. ${ }^{32}$ But in the Middle Ages these passages inspired dual traditions of interpretation. Scholastic philosophers provided commentary on Ethics 5, and as Joel Kaye has shown, this text served as a springboard for some very sophisticated economic analysis by some

${ }^{31}$ Ibid., pp. 568-69.

${ }^{32}$ An extensive argument for the unity and coherence of the passages in Politics and Ethics is provided by Scott Meikle, Aristotle's Economic Thought (Clarendon: Oxford, 1995). 
fourteenth-century scholars. ${ }^{33}$ But the Politics held greater sway over moral philosophy and canon law. ${ }^{34}$

But the canonists and other moral theologians of the late Middle Ages seem to have been inclined to seek accommodation with the burgeoning money economy, by emphasizing those portions of Aristotle that were most amenable to it, and where necessary by revising Aristotle's positions. Lester K. Little, in a well-known study, explains the high-medieval innovation of religious poverty in the context of the money economy that emerged in $12^{\text {th }}$ - and $13^{\text {th }}$-century Europe. ${ }^{35}$ Little demonstrates that the ideal of religious poverty was inspired by, predicated on, and informed by the logic of the commercial economy. Furthermore, Little shows that the scholastic philosophers, so many of whom were in the fraternal orders, were predisposed, because of their urban and commercial origins, to see commercial exchange as logical and natural. These fraternal thinkers, therefore, were at the forefront of the effort throughout the later Middle Ages to accommodate money and profit to Christian ethics. ${ }^{36}$

33 Joel Kaye, Economy and Nature in the Fourteenth Century: Money, Market Exchange, and the Emergence of Scientific Thought (Cambridge: Cambridge University Press, 1998).

${ }^{34}$ Ibid., p. 53.

${ }^{35}$ Lester K. Little, Religious Poverty and the Profit Economy in Medieval Europe (Ithaca: Cornell University Press, 1978).

${ }^{36}$ Jacques Le Goff provides a counter-argument to Little and others in Your Money or Your Life: Economy and Religion in the Middle Ages, trans. Patricia Ranum (New York: Zone Books, 1988). In "trying to show that how an ideological obstacle can fetter or 
Aquinas, in addressing the question of fraud in the Summa Theologica, restates Aristotle's distinction from the Politics between money as measure, which is necessary and useful, and money as ends, an object of accumulation, which is useless and dishonorable. But then Aquinas provides an additional stipulation:

delay the development of a new economic system" (69), Le Goff maintains that scholastic thinkers, inheritors of ancient Hebraic and Patristic suspicions of wealth and profit, consistently resisted commerce and the fiduciary innovations of the money economy, and thereby inhibited the rise of capitalism. However, in a subsequent book, Money and the Middle Ages: An Essay in Historical Anthropology, trans. Jean Birrell (Cambridge: Polity Press, 2012), Le Goff, while expanding on this topic, also concedes that "the pursuit and the use of money by individuals and by states was gradually justified and legitimized by the institution that inspired and governed them, the Church, despite the conditions it attached to this justification" (2). See also Martha C. Howell, Commerce before Capitalism in Europe, 1300-1600 (Cambridge: Cambridge University Press, 2010). The most comprehensive analysis of scholastic economic thought has been provided in a series of works by Odd Langholm; see Wealth and Money in the Aristotelian Tradition: A Study in Scholastic Economic Sources (Bergen:

Univeristetsforlaget, 1983); Economics in the Medieval Schools: Wealth, Exchange, Value, Money and Usury according to the Paris Theological Tradition, 1200-1350 (Leiden: E. J. Brill, 1992); “The Medieval Schoolmen (1200-1400),” in Ancient and Medieval Economic Ideas and Concepts of Social Justice, ed. S. Todd Lowry and Barry Gordon (Leiden: Brill, 1998). See also John T. Noonan, Jr., The Scholastic Analysis of Usury (Cambridge, MA: Harvard University Press, 1957). 
Profit which is the purpose of trade, while it does not in itself involve something honorable or necessary, also does not of its own nature imply something vicious or contrary to virtue. Nothing prevents profit from being directed to a necessary or even honorable goal, so that trade is thereby made licit. For example someone may seek to secure a moderate profit through trade to maintain his household or to support the poor or he may also engage in trade for the public welfare to provide his country with the necessities of life and seek profit not as his goal but as a recompense for his labor. ${ }^{37}$

What had began in Aristotle as a principle of the unfairness of inequitable exchange has become in Aquinas a justification of the profit of the merchant.

This is an example of what R. Howard Bloch has termed "the scholasticism of exchange":

The rise of scholasticism as an integral part of the urban revival of the High Middle Ages was even accompanied by what might be called a 'scholasticism of exchange.' Canonists and theologians struggled, against a long anticommercial tradition, to make the kinds of distinctions and connections by which profit could be justified and by which even fraud might be exculpated. ${ }^{38}$

${ }^{37}$ St. Thomas Aquinas on Politics and Ethics, ed. and trans. Paul E. Sigmund (New York: W. W. Norton, 1988), pp. 73-74.

${ }^{38}$ R. Howard Bloch, Etymologies and Genealogies: A Literary Anthropology of the French Middle Ages (Chicago: University of Chicago Press, 1983), p. 170. 
From a starting point where money and profit were considered wrong, there was an effort to make finer and finer moral distinctions, each of which made the general practice of commerce incrementally more natural and licit. At first, the seller's profit was prima facie evidence of the inequality of the transaction; soon enough, an exchange was unjust only if the seller intended fraud. ${ }^{39}$

Lianna Farber has recently made the case that fourteenth-century writers, both within the schools and in vernacular literature, were approaching a consensus on the legitimacy of trade and commercial economy, based on common notions of value, community, and consent. ${ }^{40}$ One can see such a perspective informing Gower's earlier poetry. Both Mirour de l'Omme and Vox Clamantis contain, in their depictions of the third estate, extensive anti-commercial satires. In both works, the corruption of merchants is embodied in allegorical figures. But in both cases the figure represents not money or profit (or Mede) but rather fraud-Triche in the Mirour, Fraus in the Vox. ${ }^{41}$ Nothing in these poems questions the legitimacy of commerce per se. The introduction

${ }^{39}$ See also Kaye, Economy and Nature, pp. 82-83, on the move in the $13^{\text {th }}$ century toward adjudging usury solely on the basis of intention.

${ }^{40}$ Farber, An Anatomy of Trade, pp. 1-8 et passim.

${ }^{41}$ See Roger A. Ladd, “The Mirour de l'Omme and Gower's London Merchants,” Antimercantilism in Late Medieval English Literature (New York: Palgrave Macmillan, 2010), pp. 49-75. See also Craig E. Bertolet, "Fraud, Division, and Lies: John Gower and London," in On John Gower: Essays at the Millennium, edited by R. F. Yeager (Kalamazoo, MI: Medieval Institute Publications, 2007), pp. 43-70. 
of Triche is prefaced by an assertion that merchants are not only necessary but divinely ordained:

Si une terre avoir porroit

Tous biens ensemble, lors serroit

Trop orguillouse, et pour cela

Dieus establist, et au bon droit,

Qe l'une terre en son endroit

Del autry bien busoignera:

Sur quoy marchant dieus ordina,

Qui ce q'en l'une ne serra

En l'autre terre querre doit;

Pour ce qui bien se gardera,

Et loyalment marchendera,

De dieu et homme il est benoit. $\quad[25189-25200]^{42}$

If one country had all goods together, then it would be too proud. And therefore God established, quite rightly, that any one country would properly have need of others. Thereupon God ordained merchants, who would go seek in another country whatever any one country did not have.

${ }^{42}$ The Complete Works of John Gower: The French Works, ed. G. C. Macaulay (Oxford: Clarendon, 1899). 
Therefore, he who conducts himself well and trades honestly is blessed by God and man. ${ }^{43}$

Chaucer's Parson, in his discussion of Avarice, expresses almost exactly the same sentiment:

Of thilke bodily marchandise that is leveful and honest is this: that, there as God hath ordeyned that a regne or a contree is suffisaunt to hymself, thanne is it honest and leveful that of habundaunce of this contree, that men helpe another contree that is more nedy./ And therfore ther moote been marchantz to bryngen fro that o contree to that oother hire marchandises./ That oother marchandise, that men haunten with fraude and trecherie and deceite, with lesynges and false othes, is cursed and dampnable. $\quad[\mathrm{X} .777-79]^{44}$

In Confessio Amantis, however, Gower is staking out positions closer to those of Aristotle in the Politics, and more conservative even than those of Aquinas. Book 5 of the Confessio begins by depicting a world fallen from an Edenic state. It has fallen, though, not from innocence into corruption through sin, but from commonality into private property through money:

Ferst whan the hyhe god began

${ }^{43}$ Mirour de l'Omme (the Mirror of Mankind), by John Gower, trans. William Burton Wilson, ed. Nancy Wilson Van Baak (East Lansing, MI, 1992).

${ }^{44}$ Quotations of the Canterbury Tales are taken from The Riverside Chaucer, gen. ed. Larry D. Benson (Boston: Houghton Mifflin, 1987). On this passage, see Ladd, Antimercantilism, p. 78. 
This world, and that the kinde of man

Was falle into no gret encress,

For worldes good tho was no press,

Bot al was set to the comune.

Thei spieken thanne of no fortune

Or forto lese or forto winne,

Til Avarice broghte it inne;

And that was whan the world was woxe

Of man, of hors, of Shep, of Oxe,

And than men knewen the moneie. [5.1-11]

The introduction of money, according to Gower, led people to stop seeing material as commonly owned and intended for the common good, and instead to see it as commodity destined for private property. Money does this, Gower says, by making hoarding both possible and appealing. In the Confessio, Gower does not seem to see money as functioning to facilitate exchange. On the contrary, he sees it as separating wealth from usable material in a way that inhibits the useful exchange of goods. What it promotes is the accumulation of wealth in and for itself. This leads to greed and to division - to the construction of battlements to protect hoarded wealth and to war to gain more. But as it does not correspond to use, the wealth of money brings no profit even to those who accumulate it. Gower says of the avaricious man:

So is he povere, and everemore

Him lacketh that he hath ynowh:

An Oxe draweth in the plowh, 
Of that himself hath no profit;

A Schep riht in the same plit

His wolle berth, bot on a day

An other takth the flees away:

Thus hath he, that he noght ne hath,

For he therof his part ne tath.

Since he can neither spend his wealth nor, ultimately, preserve it, the avaricious man profits from commerce no more than the ox profits from the plow. Speaking of plows and plenitude, contrast this passage from Chaucer's Shipman's Tale:

But o thyng is, ye knowe it wel ynogh

Of chapmen, that hir moneie is hir plogh.

We may creaunce whil we have a name,

But goldlees for to be, it is no game. [VII.287-90]

In the Chaucerian image, money is the plow, the harvest is credit, and the merchant is the plowman. (This is the merchant of St. Denis speaking, so it may not represent an unmediated Chaucerian perspective.) In the Gowerian image, the harvest is profit—but the merchant is the ox. Chaucer, clearly, has a sense of productive capital. Gower's view is more broadly philosophical, but his claim that the man can no more profit from an abundance of wealth than an ox can profit from the plow or the sheep from its wool derives from Aristotelian views of the accumulation of money as unnatural since it does not necessarily correspond to any practical use. Scholastic writers also emphasized the infertility of money, its inability to produce fruitful profit, and where they acknowledged 
that money was quite remarkable in its ability to reproduce itself, they characterized this as an unnatural fecundity. ${ }^{45}$

Hewing to Aristotle's anti-pecuniary critique from the Politics, the first tale Gower tells in Book 5 is that of Midas. His source is Ovid Metamorphoses XI, but Gower glosses the tale almost precisely as Aristotle does:

And thus, thogh that he mutliplie

His gold, withoute tresorie

He is, for man is noght amended

With gold, bot if it be despended

To mannes us.

Particularly notable here is Gower's use of the phrase "multiplie his gold." The meaning here is that the increase of money is vain and fruitless unless the money is converted to useful ends. And yet Gower had used the same terms in Book 4 to praise alchemists:

And also with gret diligence

Thei founden thilke experience,

Which cleped is alconomie,

Wherof the selver multeplie

Thei made and ek the gold also.

\footnotetext{
${ }^{45}$ See Kaye, Economy and Nature, p. 53, on the Aristotelian characterization of money as infertile; see also Bloch, Etymologies, p. 173, and Le Goff, Your Money, p. 29, on the scholastic amplification of the principle.
} 
But the purpose in Book 5 is to negate the value of such multiplication; the function of money is to separate wealth from use, so there is no true gain in the accumulation of gold. ${ }^{46}$ Gower brings the point home most vividly through the tale of Midas, the climax coming when his golden touch prevents him from eating, leading him to the brink of starvation.

Equally striking in Book 5 is Gower's repetition and amplification of Aristotle's claims from the Politics that greed and inequality, and in fact all strife, derive from the invention of money, and specifically from the minting of coinage:

For this a man mai finde write,

Tofor the time, er gold was smite

In Coign, that men the florin knewe,

46 "Multiplication" is a technical term of alchemy, referring to the process, distinct from transmutation, by which a substance is applied to a precious metal to increase the amount of the metal. See Principe, Secrets of Alchemy, p. 131; Duncan, "Literature of Alchemy," pp. 634-35. But Gower's use of the word "multiplie" in both alchemical and economic contexts reveals the imagined link between money and alchemy as modes for the increase of wealth. Chaucer, somewhat more self-consciously, uses the word "multiplicacioun" in both senses, and critics have recognized that Gower in the Confessio is exploiting the same ambiguity. See A. V. C. Schmidt, The General Prologue to The Canterbury Tales and The Canon's Yeoman's Prologue and Tale (New York: Holmes \& Meier, 1976), p. 154. 
Ther was welnyh noman untrewe. $\quad[5.333-36]^{47}$

Coinage here is not the sign of avarice, but the actual cause of it. The problem is money itself: the intentional, artificial abstraction of wealth.

And yet, in the Book 4 catalogue of founders of sciences, Genius credits Saturn with introducing, in addition to agriculture, coinage, and therefore commerce:

Of Chapmanhode he fond the weie,

And ek to coigne the moneie

Of sondri metall, as it is,

He was the ferste man of this...

This observation leads Genius to comment on metallurgy, and then directly to his account of alchemy. So, why are money, coinage, gold, and wealth assessed so differently in the context of alchemy than they are in the economic context of Book $5 ?$

We would be justified in judging these philosophical inconsistencies in the sprawling poem; they would not be the only ones. We could also see Gower's position in Book 5 as essentially nostalgic. But it is a radical nostalgia, and its complaint against coin may actually be more historically situated than its original in Aristotle's Politics.

When Gower refers to a past "Tofor the time, er gold was smite/ In Coign, that men the florin knewe" (5.334-35), is he referring to a legendary era of misty antiquity? Given that this passage follows the tale of Midas, we might be inclined to think so. As it happens, the Greeks did tell legends of the inventor of minting; he was Gyges, the sixth-

\footnotetext{
47 John Peter links Gower's "nostalgic" tone in this passage to other complaints against money in the Ubi sunt tradition, including Bernard's De Contemptu Mundi. Complaint and Satire in Early English Literature (Oxford: Clarendon, 1956), p. 70.
} 
century ruler of Lydia, who is described by Herodotus and whom some modern historians still credit as the first king to coin money. ${ }^{48}$ The legends of Gyges, however, are not about minting, but rather about a ring that granted invisibility, and Gower does not tell his tale. Instead, he may have had a more precise and recent era in mind. For Gower, the time "before gold was smitten into coin, and men knew the florin" would be the time before the middle of the preceding century.

The word "florin" could be used generically by medieval writers to mean coins or money. But there is a reason that the florin became synonymous with minted money; it is not just any coin. Minted in Florence first in 1252 and for three centuries thereafter, it was the first widely circulated gold coin minted since Carolingian times. It quickly became the most popular coin in the medieval world, and was the standard unit of currency in western Europe through the early Renaissance. The minting of gold coins like the florin (along with the Genoese genovino and the Venetian ducat), made possible by an influx of gold from new mines in Hungary, greatly facilitated large-scale international transactions. ${ }^{49}$ The increasing circulation of money, through trade as well as war and taxation (overseen by new state bureaucracies), laid the groundwork for what

${ }^{48}$ See David Graeber, Toward and Anthropological Theory of Value: The False Coin of Our Own Dreams (New York: Palgrave, 2001), pp. 101-102; Marc Shell, “The Ring of Gyges," in The Economy of Literature (Baltimore: Johns Hopkins University Press, 1978), pp. 11-62.

${ }^{49}$ See Peter Spufford, Money and Its Use in Medieval Europe (Cambridge: Cambridge University Press, 1988). 
some have called the commercial revolution of the long thirteenth century. ${ }^{50}$ Gower roots his critique of avarice in a complaint against coinage because he is indicting the money economy. From this perspective, Gower is justified in seeing the minting of gold into coins as the source of the social disruption he most bemoans. Gower most consistently satirizes divisiveness, and nothing is more divisive than the supplanting of the common profit that existed before money by the individual profit motive of the money economy. This is embodied by Dame Avarice's courtier Covoitise, who takth non other hiede, Bot that he mai pourchace and gete.

His conscience hath al forgete, And not what thing it mai amounte

That he schal afterward acompte. [5.2010-14]

In fact, for Gower "the time, er gold was smite/ In Coign" was more recent than the early thirteenth century. Gold coins were minted for the first time in England in 1344. The first issue was an imitation of the florin and was sometimes called an English florin, but it was a failed specie and was quickly recalled. ${ }^{51}$ It was replaced by the "noble," which was a tremendous success, becoming one of the most popular coins in Europe and the mainstay of English currency until the time of the Tudors. ${ }^{52}$ The image on the obverse of the noble, virtually unaltered for more than a century, depicted the king

${ }^{50}$ See Le Goff, Money and the Middle Ages, pp. 33-60.

${ }^{51}$ Donald C. Baker, “Gold Coins in Mediaeval English Literature,” Speculum 36 (1961): 282-87 (83).

${ }^{52}$ Spufford, Money and Its Use, pp. 282 and 379-80; Baker, "Gold Coins,” p. 284. 
enthroned on a ship. This was taken to commemorate Edward III's naval victory at Sluys, and more generally as figuring the confluence of imperial military ambitions, monarchical authority, and national economic expansion through overseas trade — all of which were in fact abetted by the issuance of this coinage. ${ }^{53}$ Explaining the proliferation of the noble, Peter Spufford observes, "In the 1350s and 1360s they were struck in enormous numbers as the ransoms and other profits of a successful war were remitted back to England in gold, along with the continuous proceeds of the sale of English wool." 54 As Donald Baker notes, the ship design on the noble "was also probably intended to inspire the merchant navy in the wool trade with Flanders." 55 The overall nationalistic effect can be seen in a passage from the early $15^{\text {th }}$-century "Libelle of Englyshe Policye":

For foure things our noble sheweth to mee-

King, ship, and swerd and power of the sea.

— But King Edward made a siege royall

${ }^{53}$ Baker, "Gold Coins," p. 284. The motto on the noble read, "I H C AUTEM TRANSIENS PER MEDIUM ILLORUM IBAT.” (“He, however, passed through the middle of them.") This has been taken to refer to the victory at Sluys, but Marc Shell (Economy of Literature, pp. 70-71) argues that it also alludes to the Ring of Gyges and its ability to grant invisibility, and that the motto links Edward III to Gyges as minters of coins.

${ }^{54}$ Spufford, Money and Its Use, p. 282. See also Le Goff, Money and the Middle Ages, p. 87.

${ }^{55}$ Baker, “Gold Coins,” p. 284. 
And wann the town and in special

The sea was kept, and thereof he was lord,

Thus made he nobles coined of record. ${ }^{56}$

Russell Peck has claimed that "Gower formulated his ideas of good and bad kingship during the reign of Edward III." $" 57$ Gower, Peck argues, was contemptuous of Edward for what he saw as the king's weakness and moral lassitude, and also for his war policies. In Confessio 5, the "division" caused by coin is seen equally in individual pursuit of profit and in war. Before gold coinage,

Tho was ther nouther schield ne spere

Ne dedly wepne for to bere;

Tho was the toun withoute wal,

Which nou is closed overal;

Tho was ther no brocage in londe, Which nou takth every cause on honde.

So mai men knowe, hou the florin

${ }^{56}$ Quoted in Baker, "Gold Coins," p. 285. On the economic nationalism of this poem, see John Scattergood, “The Libelle of Englyshe Polycye: The Nation and Its Place,” in Nation, Court and Culture: New Essays on Fifteenth-Century English Poetry, ed. Helen Cooney (Dublin: Four Courts Press, 2001), pp. 28-49; Ladd, Antimercantilism, pp. 11219.

${ }^{57}$ Russell A Peck, "The Politics and Psychology of Governance in Gower: Ideas of Kingship and Real Kings," in A Companion to Gower, edited by Siân Echard (Cambridge: D. S. Brewer, 2004), pp. 215-38 (224). 
Was moder ferst of malengin

And bringere inne of alle werre...

Of course, the social changes brought by the money economy were very real and profound. In particular, the rise of wage labor, with the formation of a class of wage laborers in the towns and the expectation of cash payment for agricultural labor, altered social relations in ways that Gower and his contemporaries were acutely aware of. There was also more immediate instability caused by the fluctuations in cash values; the fourteenth century has been seen as a period of monetary crisis. ${ }^{58}$ According to the historian Mavis Mate, "The introduction of a gold coinage had just as much impact on the English economy as the outbreak of the Black Death."59

But Gower would never have seen the problems wrought by gold currency or even the disruptions of the money economy as purely economic issues. The Confessio consistently depicts the ethical inextricably bound up with the political, and the governance of the individual mirroring the governance of the state. James Simpson has argued that "the whole poem outside Book VII is a discussion of ethics and economics, a discussion which leads inevitably to the explicit political discourse of Book VII."60 The

${ }^{58}$ See Le Goff, Money and the Middle Ages, pp. 82-93.

${ }^{59}$ Mavis Mate, "The Role of Gold Coinage in the English Economy, 1338-1400," The Numismatic Chronicle 18 (1978): 126-41 (126).

${ }^{60}$ James Simpson, Sciences and the Self in Medieval Poetry: Alan of Lille's Anticlaudianus and John Gower's Confessio amantis (Cambridge: Cambridge University Press, 1995), p. 220. See also Russell A. Peck, Kingship \& Common Profit in Gower's 
economics that Simpson refers to, Gower's "iconomique," means, as it does in Aristotle, the governance of the household, but in Gower it is, like the self, a microcosm of society. "The Confessio amantis as a whole," Simpson says, "reveals that there is no escape from politics. ${ }^{, 61}$ It is entirely consistent, therefore, that in decrying the power of commerce to divide the social fabric and to undermine the common profit, Gower would focus on the minting of gold coins, which in his time was sanctioned by the king as both the symbol and the instrument of state power wedded to mercantile ambition. Gower's perspective is fundamentally nostalgic, but he is nonetheless be farsighted enough to see how much power would soon be invested in the centralized state through capitalism, and how difficult it would become to maintain the cherished ideal of kingly moral leadership when royal interests were married to the expansion of the national commercial economy.

This would explain why Gower criticizes money and coinage in Book 5 of the Confessio while praising alchemy and its quest for wealth in precious metals in Book 4 . While anti-alchemical treatises accused the alchemists of artificially generating imitation gold, and therefore counterfeiting wealth, the alchemists themselves and their supporters insisted that they augmenting the true content of metals through entirely natural processes. Gower therefore emphasizes that alchemy works in accordance with "kinde"-nature:

This craft is wroght be weie of kinde,

So that ther is no fallas inne...

Confessio Amantis (Carbondale and Edwardsville: Southern Illinois University Press, 1978), pp. 99-123.

${ }^{61}$ Ibid., p. 264. 
These olde Philosophres wyse

Be weie of kinde in sondri wise

Thre stones maden thurgh clergie... [4.2531-33]

Ther is algate founde a wyte,

So that thei folwe noght the lyne

Of the parfite medicine,

Which grounded is upon nature...

For Gower, as for scholastic defenders of alchemy like Albertus Magnus, ${ }^{62}$ alchemy is not supernatural, nor is it "artificial," in the sense of invented. It is empirical; Gower refers from the start to the "experience / Which cleped is alconomie" (4.2458-59). And as Gower repeatedly states, all of the metals exist on a continuum, with silver and gold and the two extremes. So the alchemical process is not one of "transmutation," but rather of multiplication: "It makth multiplicacioun / Of gold" (4.2573-74). Alchemy seeks to "multiply" the gold or silver in a substance by bringing out its essential nature.

Alchemists perfect the substance, by leading it to the ideal it naturally longs for. "For thei tuo"- that is, gold and silver_-"ben thextremetes,/ To whiche after the propretes/ Hath every metal his desir/ With help and confort of the fyr" (4.2565-70). Alchemy does not make something out of nothing, and it does not change one substance into another. It increases what is essentially already there.

Gower begins Book 5 of the Confessio with the words, "Obstat auaricia nature legibus"-_Avarice obstructs the laws of nature." Gower endorses alchemy before he excoriates money because alchemy stands in contrast to mercantilism as a myth of natural

\footnotetext{
${ }^{62}$ See Newman, Promethean Ambitions, pp. 45-48.
} 
wealth. Alchemy in Book 4 is everything that money in Book 5 is not: ordered, organic, bounded by natural extremes, rational, obedient to consistent laws, commensurable, and equitable. One of the qualities of money that most disturbed ancient and medieval thinkers was that, through exchange and interest, it seemed to be able to multiply itself, and therefore to create wealth ex nihilo, without labor or material. ${ }^{63}$ But in Gower's understanding, the alchemist's labor leads the material, through "the comfort of the fire," to the ideal form it most desires.

Some of the greatest minds of the $13^{\text {th }}$ and $14^{\text {th }}$ centuries worried that alchemy, by increasing the amount of (natural or synthetic) gold and silver, could destabilize the money economy. Gower seems to have harbored greater concerns about the destabilizing effects of the money economy itself. Alchemy for Gower was a myth of profit without money or exchange, of value that is absolute rather than relative, of wealth that is organic, natural, universal, elemental, and inalienable from the innate value of material. Alchemy allowed him, as it must have allowed many of his contemporaries, to entertain a vision of labor, wealth, and profit while maintaining his belief in a moral social system rooted in ancient concepts of justice and fair exchange. The elixir, Gower says, can refine every metal, "And pureth hem be such a weie / That al the vice goth aweie" (4.2555-56).

But, it is also lost. The science itself is true, but we cannot recover it to the modern world, which, even by Gower's time, was thoroughly monetized.

${ }^{63}$ See Le Goff, Your Money or Your Life, pp. 29-30. 


\section{Chaucer: "That slydynge science"}

"But al be that he was a philosophre," Chaucer says of the Clerk in the General Prologue, "Yet hadde he but litel gold in cofre" (I.297-98). The joke reveals that Chaucer associates practical philosophy with alchemy, and alchemists with dishonest wealth. This offhand remark at the beginning of the Canterbury Tales, though, hardly prepares the reader for the extensive attack on alchemy that arises abruptly near the end.

There is much that is anomalous about the Canon's Yeoman's Prologue and Tale. ${ }^{64}$ There is, first, the abrupt intrusion into the Canterbury pilgrimage of an additional wayfarer, as the burnt and bedraggled Yeoman and his heavily sweating Canon come galloping up to join the fellowship as the are passing Boughton-under-Blee. The Yeoman, identifying himself to the curious Host, begins subtly to reveal the Canon as an alchemist, and the Canon flees in consternation, leaving the Yeoman to expound at much greater length. The anomalousness continues with what the Ellesmere confusingly labels Parts I and II of the Canon's Yeoman's Tale-really a confessional prologue and related tale, in the manner of the Wife of Bath and the Pardoner. ${ }^{65}$ In Part I, the Yeoman bitterly recalls the time, effort, and money he has lost in the workshop of his alchemical Canon, and indicts the hopelessly complicated obfuscations of alchemical theory. In Part II, the tale, he tells of an alchemical canon-a different one, he insists, and a pure charlatan-

\footnotetext{
${ }^{64}$ See Judith Scherer Herz, “The Canon's Yeoman's Prologue and Tale," Modern Philology 58 (1961): 231-37.

${ }^{65}$ See Joseph E. Grennen, “Saint Cecilia's 'Chemical Wedding': The Unity of the Canterbury Tales, Fragment VIII," JEGP 65 (1966): 466-81.
} 
who cons a London priest. ${ }^{66}$ The Yeoman's choler is unusual as well. Chaucer's portraits of scoundrels are typically in the first person, or at least from the scoundrels' own perspectives rather than those of their victims, and often colored with a not entirely feigned admiration for their ingenuity; in general, he just gives them enough rope to hang themselves.

As the pilgrims wonder what is so urgent in the pair's sudden appearance, readers have wondered what is so important in alchemy as a theme to merit its unusual and sudden introduction so late in the Canterbury frame scheme, as well as the Yeoman's vehement denunciations. There has been no sufficient explanation for why Chaucer goes out of his way to excoriate alchemy. His stance has sometimes been labeled conventional, but as Gower's treatment of the topic reveals there were actually competing conventions. In fact, as Stanton J. Linden has shown, Chaucer is not following a tradition of alchemical satire, but initiating one: 'In the Canon's Yeoman's Prologue and Tale we have the earliest significant artistic use of alchemy and the beginning of a long tradition-extending from the fourteenth century through the sixteenth and well into the

\footnotetext{
66 The London setting, too, is an anomaly. Other than the abortive Cook's Tale, the Canon's Yeoman's is the only tale Chaucer sets in the city itself, a point explored by David Wallace in "Chaucer and the Absent City," in Chaucer's England: Literature in Historical Context, edited by Barbara Hanawalt (Minneapolis: University of Minnesota Press, 1992), pp. 59-90 (particularly 81-83).
} 
seventeenth - in which a negative attitude toward the art and its practitioners is assumed and the reasons for this attitude exploited." 67

${ }^{67}$ Stanton J. Linden, Darke Hierogliphicks: Alchemy in English Literature from Chaucer to the Restoration (Lexington: University of Kentucky Press, 1996), p. 44. On the traditional perception of alchemists as frauds, see also Tara Nummedal, "On the Utility of Alchemical Fraud," in Chymists and Chymistry: Studies in the History of Alchemy and Early Modern Chemistry, edited by Lawrence M. Principe (Sagamore Beach, MA: Science History Publications, 2007), pp. 173-180. Linden remarks “enough has been written to redirect attention, once and for all, from conjecture about Chaucer's possible victimization at the hands of a real alchemist to explain the sudden appearance of a Yeoman and his Canon in the company of those with whom they alone did not set out from Southwark" (42). That conjecture dates at least to the eighteenth century (see Linden, p. 305 n. 24) and was elaborated, naturally, by John M. Manly in Some New Light on Chaucer (New York: Holt, 1926), pp. 246-47. An even older tradition, from the fifteenth century, holds that Chaucer's detailed knowledge of alchemical lore reveals him as a adept and practitioner of the craft. See Robert M. Schuler, "The Renaissance Chaucer as Alchemist," Viator 15 (1984): 305-33; Edgar H. Duncan, “The Literature of Alchemy and Chaucer's Canon's Yeoman's Tale: Framework, Theme, and Characters," Speculum 43 (1968): 633-56 (particularly p. 656); Gareth W. Dunleavy, "The Chaucer Ascription in Trinity College, Dublin MS D.2.8," Ambix 13 (1965): 2-21; Anke Timmermann, "New Perspectives on 'The Chaucer Ascription in Trinity College, Dublin MS D.2.8," Ambix 53 (2006): 161-65. This view, too, has its modern adherents; see Jonathan Hughes, The Rise of Alchemy in Fourteenth-Century England (London: 
Perhaps because of this, and perhaps also because the Yeoman's critique of alchemy is in parts nearly as recondite as its object, the Canon's Yeoman's Tale has been less studied than many of the Canterbury Tales. In recent years, though, interest has increased in the Canon's Yeoman's sequence, and much of the analysis has been acute. Three analyses in particular share both this critical standard of excellence and also a fruitful focus on science, technology, and economics as the text's most significant themes.

Britton Harwood offers a Marxist reading of the Canon's Yeoman's Tale as a “mystification of work," an example of Chaucer's refusal to dramatize "productive capital"- payment for labor to make a product that is not owned by the laborer but is sold by the investor for profit. ${ }^{68}$ For Harwood, the Yeoman is "the only wage laborer anywhere in Chaucer - the only laborer hired to make a commodity," and alchemy mimics industrial labor only to obscure it with magic and exoticism. ${ }^{69}$ Lee Patterson also

Continuum, 2012), pp. 75-76. Others, like Principe, make the more reasonable claim that "Chaucer does not... conclude that transmutational alchemy is false; rather, it is a privileged kind of knowledge with which only a select few should dare to meddle" (The Secrets of Alchemy, p. 182), but I think that much more accurately describes Gower's positions than Chaucer's.

${ }^{68}$ Britton J. Harwood, “Chaucer and the Silence of History: Situating the Canon's Yeoman's Tale," PMLA 102 (1987): 338-350 (342).

${ }^{69}$ Ibid., p. 343. 
sees the Yeoman as exploited labor, "a personal servant, perhaps even an apprentice."70 Expanding on Harwood's analysis, Patterson claims that alchemy in the tale offers the promise not only of wealth but of a theoretical and empirical advancement in the human condition, that is, of technology, and when it proves false the Yeoman is disabused but maintains this technological view of human practice as well as a technologized sense of himself as a modern individual, making him the ideal subject to embrace modernity and capitalism. And Peggy Knapp links Chaucer's text to Ben Jonson's The Alchemist, for their emphasis on work and their use of alchemy to satirize nascent capitalism. ${ }^{71}$ Like Harwood and Patterson, Knapp sees the Yeoman as a laborer in the Canon's technological industry, but in the Yeoman's rebellion against the his lord she also sees the Marxian potential for the demystification of the workings of the capitalist process and the self-actualization and liberation of the worker. Knapp concludes that "modernity inhabits this tale." 72

All of these approaches share a very fruitful emphasis on science, technology, and economics in the Canon's Yeoman sequence. But they also share a progressive view of economics, a Marxian view of labor and capital, and a view of alchemy as a metaphor for both capitalism and for industrial technology, all of which may not be entirely

${ }^{70}$ Lee Patterson, "Perpetual Motion: Alchemy and the Technology of the Self," Studies in the Age of Chaucer 15 (1993): 25-57 (30).

${ }^{71}$ Peggy Knapp, “The Work of Alchemy," Journal of Medieval and Early Modern Studies 30 (2000): 575-99.

72 Ibid., p. 584. 
appropriate to this text, and may in fact obscure Chaucer's own particular fourteenthcentury understanding of science, technology, and economics.

It is necessary, first, to reconsider the reading of the Yeoman as industrial wage laborer. The critical tradition of taking the Yeoman to be the Canon's paid employee or indentured apprentice seems to derive primarily from the meaning in other contexts of the word "yeoman." Everything in the Yeoman's own description of the alchemical workshop suggests a collective enterprise:

I wol speke of oure werk.

What we been there as we shul exercise

Oure elvysshe craft, we semen wonder wise,

Oure termes been so clergial and so queynte...

Oure orpyment and sublymed mercurie,

Oure grounden litarge eek on the porfurie,

Of ech of thise of ounces a certeyn-

Noght helpeth us; our labour is in veyn.

Ne eek oure spirites ascencioun,

Ne oure materes that lyen al fix adoun,

Mowe in oure werkyng no thyng us availle,

For lost is al oure labour and travaille;

And al the cost, a twenty devel waye,

Is lost also, which we upon it laye.

[VIII.749-53, 774-83]

${ }^{73}$ See Patterson, "Perpetual Motion,” p. 30. 
The Yeoman's language suggests, most conspicuously in his pervasive use of the firstperson plural, that he is not merely a servant but a partner in the endeavors of the Canon's workshop. In fact, while he complains of the time and pains and injuries of his labor, he quite explicitly figures himself as a capital investor in the alchemical enterprise. After yet another kiln explosion ruins another attempt to realize the Canon's theories, the Yeoman imagines one of his anonymous partners asserting,

Us moste putte oure good in aventure.

A marchant, pardee, may nat ay endure,

Trusteth me wel, in his prosperitee.

Somtyme his good is drowned in the see, And somtyme comth it sauf unto the londe. [VIII.946-50]

The Yeoman and his collaborators do not think they are wage-laborers or servants.

Is this just the false consciousness of an essentially proletarian worker? There is a greater problem with thinking of the Yeoman as the alienated laborer of industrial capitalism. Even if the Canon were paying the Yeoman for his services, it would not really be appropriate to characterize alchemy as "productive capital" in as much as, from Chaucer's perspective - and this is the core of the Yeoman's entire discourse - alchemy does not and cannot produce anything. ${ }^{74}$ Lawrence Principe, reacting to a modern

${ }^{74}$ What this might indicate is that not even the Canon's Yeoman is a wage-laborer, and that productive capital is even more thoroughly erased from the Canterbury Tales than Harwood claims. If so, this would point toward some of the facts of economic life in a market society that Chaucer was not conscious of and that mark his work with their 
tradition that has often taken alchemy as essentially a set of philosophical or theoretical tropes, emphasizes that in its historical contexts alchemy was "a productive enterprise. Producing new materials and transforming or improving common ones forms a central theme within alchemical tradition."75 For historians of science, this is key, as the empirical practices of alchemy can be shown to lay the groundwork for much later science, particularly in chemistry. But for understanding Chaucer, it is more important to recognize that his Canon's Yeoman does not believe alchemy capable of anything but wasting one's time, labor, and money. The Yeoman's primary complaint is not of being exploited by the Canon but of being deceived by alchemy. ${ }^{76}$

Patterson acknowledges that "the discourse of alchemy raises the problem of the verbal representation of truth with a special intensity and sophistication."77 But he and others critics, including Knapp, see alchemy as fostering a technologized mentality that laid the groundwork for modernization. In this, they are again following historians of science, notably Principe and Newman, who advance an "empiricist" understanding of alchemy. No one denies that the pursuit of the "multiplying" of metals was vain or that many alchemists were crackpots or charlatans, but the empiricist view holds that

absence. But if we want to know what Chaucer did think about alchemy and economics, productive capital and wage labor are not the keys.

${ }^{75}$ Principe, Secrets of Alchemy, p. 208 (emphasis Principe's.) See also Newman and Principe, Alchemy Tried in the Fire, pp. 38-44.

${ }^{76}$ See Richard Firth Green, "Changing Chaucer," Studies in the Age of Chaucer 25 (2002): 27-52.

${ }^{77}$ Patterson, "Perpetual Motion,” p. 39. 
alchemy, often in defiance of a more hidebound hierarchy that privileged only textual authority, nonetheless combined theory and practice in a novel way that anticipated modern science. Newman claims that "the alchemists of the Middle Ages developed a clearly articulated philosophy of technology, in which human art is raised to a level of appreciation difficult to find in other writings until the Renaissance." ${ }^{78}$ Principe also argues for the integral role of alchemy in the development of technological and scientific modes of thought, and he places the arrival of alchemical lore in Western Europe within the context of the "Renaissance of the Twelfth Century." But Principe acknowledges that alchemy was only one of many fields of technical learning that became available or more widely accessible to Western Europeans at the same time: "Muslim scholars had made their own considerable advances, providing Europeans with a wealth of additional knowledge and ideas in astronomy, medicine, mathematics, physics, mechanics, botany, engineering, and fields completely new to Europe — such as al-kimiya'. In the twelfth century, Europe not only accepted these ideas but hungered for them."79 A case can be made that the experimental protocols and empirical processes of alchemy made special

\footnotetext{
${ }^{78}$ William Newman, "Technology and the Alchemical Debate in the Late Middle Ages," Isis 80 (1989): 423-45 (433). See Patterson, “Perpetual Motion,” p. 51.

${ }^{79}$ Principe, "Secrets of Alchemy," p. 52. See also Edward Grant, The Foundations of Modern Science in the Middle Ages: Their Religious, Institutional, and Intellectual Contexts (Cambridge: Cambridge University Press, 1996), particularly pp. 168-206; Marie-Thérèse d'Alverny, "Translations and Translators," in Renaissance and Renewal in the Twelfth Century, ed. Robert L. Benson and Giles Constable with Carol D. Lanham (Cambridge, MA: Harvard University Press, 1982), pp. 421-62 (particularly pp. 439-57).
} 
contributions to the birth of scientific thought. ${ }^{80}$ But the question is why we should consider the discipline important to Chaucer's intellectual development when he is so overtly hostile to it. There is, I think, another technology that better fits the bill, one that Chaucer demonstrates a keen interest in throughout the Canterbury Tales, that functions efficaciously in everyday practice, and that was inspired by and also inspired complex theoretical and analytical thought, often in a context that associates it with protoscientific views of nature and with analytical measurement of natural phenomena. That technology is money.

The case for money as a technology has been made by Joel Kaye. Kaye specifically refers to "the technological form of money in exchange." In this form, Kaye maintains, money amounts to "an extendable, divisible, graded, and numbered continuum used as a common measuring scale, capable of expressing constantly shifting and diverse values in common numerical terms, and thus facilitating relation between seemingly incommensurable goods and services in exchange." 81 In this technological form, Kaye is able to locate in money the rationalist and scientific impetus that Newman and the literary critics that follow him find in alchemy.

Kaye's project is to construct a social context for a remarkable branch of thought in the first half of the fourteenth century. During this period, a group of scholars known

${ }^{80}$ One of the strongest arguments for this view is made by William R. Newman in Atoms and Alchemy: Chymistry and the Experimental Origins of the Scientific Revolution (Chicago: University of Chicago Press, 2006).

${ }^{81}$ Kaye, Economy and Nature, p. 171. See also Multhauf, Origins of Chemistry, pp. 15152. 
later as the "Oxford Calculators" as well as some of their contemporaries at the University of Paris engaged in a range of studies of measurement and quantification of a wide variety of social and natural phenomena. The impetus for this "measuring mania," Kaye maintains, was money. Although as university scholars they were presumably removed from the world of the marketplace, these thinkers could not help, if only because of the exigencies of university administration, being immersed in the thoroughly monetized society of the thirteenth and fourteenth centuries.

Scholars were already engaged in debates on Aristotelian theories of money, business, and ethics, as well as problems of measurement of a physical universe they conceived as existing along series of continua not divisible into discrete units. Their practical experience with money in the commercial economy exposed them to a system that made equivalencies among widely disparate objects and ideas—commodities and products; time and effort; labor and expertise; scarcity and demand. Through this, Kaye argues, scholars came to see money in its technological form: "When people of the fourteenth century looked at coined money in their hand, they saw a round, discrete object — in rough geometrical terms, a point. However, as writers on money from Aristotle through the scholastic theorists to the twentieth century have realized, money in fact functions as a line, a connecting medium (to use the word attached to it by Aristotle and the scholastics), a measuring scale composed of a divisible and expandable continuum of value." Kaye calls this model "the technological form of money in exchange": "an extendable, divisible, graded, and numbered continuum used as a common measuring scale, capable of expressing constantly shifting and diverse values in 
common numerical terms, and thus facilitating relation between seemingly incommensurable goods and services in exchange." 82

Philosophers in Oxford and Paris produced treatises of considerable subtlety and complexity, which they then shared and debated. Such economics inspired these scholars to analyze a range of phenomena and systems in the social and natural worlds, applying from economics methods of measurement with abstract but discrete units. "Every 'quality' capable of increase or decrease, whether physical or mental, came to be visualized as a divisible, continuous magnitude in the process of expansion or contraction," Kaye explains. "In Oxford and Paris, elaborate logical and mathematical languages were devised to describe and conceptually measure quantified qualities now conceived as divisible continua." 83 This application of analytical measurement to the natural world, Kaye concludes, lay the foundation for the scientific advances of subsequent centuries.

Chaucer, of course, was no "Oxford Calculator." He did not attend university; he was a layman and a secular poet; he wrote in the second half of the fourteenth century. But he was immersed in the world of money and commerce throughout his life, very often in the kind of administrative position that Kaye sees as key to the perspectives of fourteenth-century scholastics. (He would therefore have dealt daily with what Kaye calls "the technological form of money in administration": "a continuous numbered scale superimposed by the administrator on a given problem in measurement and gradation, to

\footnotetext{
${ }^{82}$ Ibid., p. 171.

${ }^{83}$ Ibid., pp. 166-67.
} 
the end of finding ranges of equalization and points of proportional division." $)^{84}$ Much of Chaucer's poetry—notably in the Shipman's Tale — reveals an interest in the workings of money and commerce, and of remarkably sophisticated forms of monetary valuation and exchange, what modern economists call "financial instruments." Also, throughout his career-from the complicated disquisitions on acoustics in House of Fame to the technological instruction of the Treatise on the Astrolabe- he demonstrated an interest in science and the measurement of natural phenomena. And we can see the confluence of these two interests in, among other places, the Summoner's Tale, where the friar's pursuit of a reasonably divisible sum of money is converted through the "unexpected gift" into an obscene and seemingly absurd challenge of dividing into equal quantities an apparently intangible substance: "To parte that wol nat departed be/ To every man yliche" (III.2214-15). ${ }^{85}$

What I am proposing, then, is that Chaucer had considerable experience with the "technological form of money," that he was interested enough in it to represent its operations complexly and in detail in much of his work, and that he on some level also comprehended it as an application of a theoretical system we might (though he did not) call economics. ${ }^{86}$ Furthermore, his understanding of the social technology of money

\section{${ }^{84}$ Ibid., pp. 174-75.}

${ }^{85}$ See Robert Epstein, "Sacred Commerce: Chaucer, Friars, and the Spirit of Money," in Sacred and Profane in Chaucer and Late Medieval Literature, ed. Robert Epstein and William Robins (Toronto: University of Toronto Press, 2010), pp. 129-45.

${ }^{86}$ Naturally, Chaucer also had experience with the physical form of money, that is, with coin, and he could characterize it in a tone that recalls Gower. For instance, when the 
abetted his comprehension of the phenomenological systems of the natural world, that he saw that natural processes could be perceived as measurable, predictable, and rational, and that this amounted to an incipiently scientific world view.

If so, then Chaucer would not need alchemy to gain a technological or scientific perspective. On the contrary, in comparison to more practical technologies, alchemy would appear to him to be misleading and insufficient. And on the evidence of the Canon's Yeoman's sequence, it did.

The Yeoman's complains first and foremost of the frustration inherent to the practice of alchemy. ${ }^{87}$ Faced with failure after failure in their efforts to produce the desired metallurgical effects, the Yeoman and his partners find themselves in the

Pardoner's three "riotours" seek Death under an oak, they find "floryns fyne of gold ycoyned rounde" (VI.770). Not all of Chaucer's references to coinage are so pejorative; the Miller says of Alison, "Ful brighter was the shynyng of her hewe / Than in the Tour the noble yforged newe” (I.3255-56). See Baker, "Gold Coins,” pp. 282, 286. Notably, when the canon in the Canon's Yeoman's Tale persuades the priest to hazard his gold in the prospect of multiplying it in the canon's laboratory, the priest fetches his store of English gold coins: "This preest the somme of fourty pound anon / Of nobles fette" (VIII.1364-65).

${ }^{87}$ On Chaucer's treatment of alchemy, see John Reidy's explanatory notes to the Canon's Yoeman's Prologue and Tale in the Riverside Chaucer, pp. 946-51. See also Edgar Hill

Duncan, “The Yeoman's Canon's 'Silver Citrinacioun,”” Modern Philology 37 (1940): 241-62, as well as Duncan, “The Literature of Alchemy and Chaucer's Canon's Yeoman's Tale." 
impossible position of trying to reproduce erroneous results, and ever hopeful, they are rewarded only with lost materials and oven explosions and wasted time and effort and expense. If we were to seek a modern analogue to alchemy as conceived by the Canon's Yeoman, it would be neither commercial manufacturing, as Harwood suggests, nor chemical engineering, as Patterson and Newman imply. It would instead be cold fusion - a seemingly scientific process that leads its hopeful adherents down a rabbit hole of impossible duplication.

But the Yeoman also stresses that alchemy is as flawed in theory as it is in practice. Alchemical doctrine seems at first convincingly concrete, with a vast lexicon of materials and methods, and a philosophy, rejecting magical thinking, that places it firmly in the realm of natural process and invariable universal laws. But the deeper it is pursued, the more it deliquesces into evasiveness and obscurantism, the alchemist's notorious "secree" and "privetee." The "cursed craft" (VIII.830) is simply impervious to direct investigation, as the Yeoman illustrates with an anecdote of a disciple of Plato,

That on a tyme seyde his maister to, As his book Senior bere witnesse, And this was his demande in soothfastnesse:

"Telle me the name of the privee stoon."

And Plato answerde unto hym anoon,

"Take the stoon that Titanos men name."

"Which is that?" quod he. "Magnasia is the same,"

Seyde Plato. "Ye, sire, and is it thus?

This is ignotum per ignocius. 
What is Magnasia, good sire, I yow preye?"

"It is a water that is maad, I seye,

Of elementes foure," quod Plato.

"Telle me the roote, good sire," quod he tho,

"Of that water, if it be youre wil."

"Nay, nay," quod Plato, “certein, that I nyl.” [ [VIII.1449-64]

Ultimately, the Yeoman concludes, alchemical theory can offer nothing more than “ignotum per ignocius," a logical fallacy of explaining the unknown with more unknowns - deception by infinite regress.

Thus Canon's Yeoman's "Plato" explains to his skeptical disciple why he cannot reveal to him the ultimate source of the "privee stoon":

“The philosophres sworn were everychoon

That they sholden discovere it unto noon,

${ }^{88}$ On Chaucer's invention of this anecdote, see Reidy, p. 951, and Julius Ruska, “Chaucer und das Buch Senior," Anglia 61 (1937): 136-137. The book Chaucer refers to is a Latin translation of a $10^{\text {th }}$-century Arabic work by Muhammad ibn Umail, Epistle of the Sun to the Crescent Moon. Reidy, citing an unpublished paper by Edgar Hill Duncan, explains that Chaucer's understanding of the title of work as Senior and the author as Plato derive apparently from the annotations in a fourteenth-century English manuscript. But Chaucer seems very deliberately to have fashioned a few sentences of Latin alchemical lore into his exemplum of an alchemical Plato and his deployment of ignotum per ignocius. The relevant passages from Chaucer's Latin source text are published in Bryan and Dempster, Sources and Analogues, pp. 697-98. 
$\mathrm{Ne}$ in no book it write in no manere.

For unto Christ it is so lief and deere

That he wol nat that it discovered bee,

But where it liketh to his deitee

Men for t'enspire, and eek for to deffende

Whom that hym liketh; lo this is the ende." [VII.1464-71]

Chaucer is apparently untroubled by the anachronism of Plato claiming that alchemy is "unto Christ... so lief and deere." This is an exemplary anecdote in the Canon's Yeoman's critique, meant to illustrate the ways in which alchemists sophistically lead their acolytes on while always refusing to ground their claims in observable fact. The claim that God loves the secret too much to allow it to be discovered, except when it mysteriously and unpredictably "liketh to his deitee" to reveal it in order to provide inspiration, is merely "Plato""s last rhetorical gambit, after which he tries to cut off further questions: "lo, this is the ende."

Oddly, "Plato""s assertion that "unto Christ it is so lief and deere" has frequently been taken as Chaucer's own avowal of the ultimate holiness and authenticity of alchemy. But the Canon's Yeoman's own conclusion makes it clear that he finds alchemy insupportable:

Thanne conclude I thus, sith that the God of hevene

Ne wil nat that the philosophres nevene

How that a man shal come unto this stoon,

I rede, as for the beste, lete it goon.

For whoso maketh God his adversarie, 
As for to werken any thyng in contrarie

Of his wil, certes, never shal he thryve,

Thogh that he multiplie terme of his lyve.

And there a poynt, for ended is my tale.

God sende every trewe man boote of his bale!

[VII.1472-81]

This bears some resemblance to Gower's assertion that modern men should not seek after the secrets of alchemy, but it is fundamentally different. Gower's claim is that alchemy is an authentic, empirical discipline, asserting that "The science of himself is trewe" (4.2598) and that "ther is no fallas inne" (4.2509). In Gower's telling, alchemy was discovered and perfected by the ancients, but it is now entirely a lost art. But Chaucer (through a wholly unauthorized alteration of sources) depicts Plato, among the most authoritative of ancient philosophers, as unable and unwilling to ground the claims of alchemy in empirical observation. The Canon's Yeoman's conclusion, that God does not wish philosophers to identify the process of coming to the stone, is his way of saying that this supposedly secret knowledge simply is not accessible to man though the systematic observation of natural processes. He who seeks the secrets of alchemy, he says, "maketh God his adversarie"-not, primarily, in the sense that this occultism is cursed, but rather in that God has not allowed its supposed truths to be accessible through the application of reason to the created world-which is to say, it is not scientific.

Alchemy is, in the Yeoman's term, "that slydynge science” (VIII.732), that slippery science, that maintains the appearance of rationality and holds out the promise of practicality but cannot deliver. Chaucer comes to alchemy with a notion of what science should be, derived from other sources - including, I am suggesting, the operation of 
money in a market economy. It entails regular measurement of results along consistent continua, observable phenomena, and logically accessible rules that can explain and predict results. Historians may well demonstrate that medieval alchemy manifested all of these qualities, but Chaucer seems not to have seen it so. And alchemy therefore looks to him like a pseudo-science.

And yet, in this context, I think the economic elements of alchemy are even more central to the significance of the Canon's Yeoman's Tale. In fact, the most important part of the tale is one that is seldom noted even by those who have shown an interest in this understudied text. It is not the ostensible "actual work" of the alchemical workshop - the priest and the canon laboring to manipulate metals in the flames - but rather the lure that the canon uses to take in the priest in the first place.

The canon, of course, is playing a con. At the core of every con is not the betrayal of the mark's confidence but rather the rapport that the conman constructs in order to obtain that confidence. The concept is best described by another arch-conman of fiction, the veteran grifter Mike, played by Joe Mantegna in David Mamet's film House of Games: "The basic idea is this: it's called a 'confidence' game. Why? Because you give me your confidence? No. Because I give you mine." 89 At the conclusion of his

${ }^{89}$ David Mamet, House of Games: The Complete Screenplay (New York: Grove Press, 1985), p. 34. This initial part of the classic con is called the "rope" by the early twentieth-century American conmen in David Maurer's classic sociological study, The Big Con: The Story of the Confidence Man (1940; reprint New York: Anchor Books, 1999). 
tale, Chaucer says as much of his crooked canon: "Thus maketh he is introduccioun,/ To brynge folk to hir destruccioun" (VIII.1386-87).

Therefore, in what is by far the cleverest part of the Canon's Yeoman's Tale, the canon goes about gaining the priest's trust by first approaching him to ask for a loan. Chaucer tells us precisely one thing about this priest of London who is the canon's target:

In Londoun was a preest, an annueleer,

That therinne dwelled hadde many a yeer,

Which was so plesaunt and so servysable

Unto the wyf, where as he was at table,

That she wolde suffre hym no thyng for to paye

For bord ne clothyng, wente he never so gaye,

And spendynge silver hadde he right ynow.

[VIII.1012-18]

The most obvious point here is that the priest has enough cash on hand to make him a worthwhile mark for a conman. But the passage also reveals that the priest has the kind of mentality to make him a likely mark. The priest's landlady finds him "so plesaunt and so servysable" that she suspends his contractual obligation to pay for his board. The priest responds not by recognizing any obligation to return the landlady's generosity, but by blithely embracing the windfall as a personal profit. What this tells us is that the priest is accustomed to benefiting materially from a suspension of the usual economic rules. The canon must see this as well, and recognizes in him the quintessential quality of a mark: a sense of entitlement.

The canon's "introduccioun" to the priest could hardly be more simple. He asks the priest to lend him a mark, and promises to pay it back in three days. The priest 
agrees, and three days later, the canon pays him back the mark. The priest is tremendously impressed by this. It shows him that the canon "so trewe is of condicioun/ That in no wise breke wole his day;/ To swich a man I kan never seye nay" (VIII.103941). "What!" replies the canon, sholde I be untrewe?

Nay, that were thyng yfallen al of newe.

Trouthe is a thyng that I wol evere kepe...

God thanke I, and in good tyme be it sayd,

That ther was nevere man yet yvele apayd

For gold ne silver that he to me lente,

Ne nevere falshede in myn herte I mente...

Syn ye so goodlich han been unto me,

And kithed to me so greet gentillesse,

Somwhat to quyte with youre kyndenesse... (VIII.1042-44, 1048-51, 1053-55) The canon offers to reveal to the priest the "pryvetee" of his "philosophie." Later, the canon will "allow" the Priest to perform alchemical maneuvers with his own hands "in tokenyng I thee love" (VIII.1153).

The tricks that the canon performs in the rest of the tale, the trade secrets of alchemy that the Yeoman is betraying, turn out not to be particularly impressive in their sophistication or ingenuity. The canon employs no dazzling mental one-upmanship, but rather readymade props, like a hollowed-out ember in which silver filings are hidden, and sleight-of-hand, and sometimes simply the crudest form of misdirection; the canon simply gets the priest to look away, and substitutes a silver ingot for a copper ingot. 
Anyone but a willing gull would see through these tricks easily; they work only because the priest's confidence has already been established.

For the Yeoman, the moral is clear: "Ful sooth it is that swich profred servyse/ Stynketh" (VIII.1066-67). Unrequested favors stink. It is the motto of all con men; Mamet's Mike puts it only slightly differently: "Don't trust nobody." 90 The London priest's particular folly is to think that because the canon repays his debt on time and without having to be hounded, it indicates that the loan established a personal relationship beyond the economic transaction. After a simple monetary exchange-the priest lends the canon one mark; the canon pays it back - the canon gets the priest to slide into the romantic language of honor, fealty and obligation: "trouthe"; "bileve"; "gentillesse"; "kyndenesse"; "love tokenyng."

${ }^{90}$ Mamet, House of Games, p. 37.

${ }^{91}$ Although the canon is, in terms of his plan, earning what we term the priest's "confidence," to the priest's understanding the canon is establishing his "credit"—a word that was coming to connote both moral character and commercial reliability. Martha C. Howell remarks that "in this culture personal honor, what was coming to be called a man's 'credit,' was not only the mark of social legitimacy but also the essential guarantor of market integrity" (Commerce before Capitalism, p. 151). The canon's romance language, though dramatically ironic as well as jarring to the modern reader, arises organically from the fiduciary context that the canon has created for the priest. As Howell notes, "A man of credit had become a man of honor" (29). See also Craig Muldrew, The Economy of Obligation: The Culture of Credit and Social Relations in Early Modern England (New York: St. Martin’s Press, 1998). 
the Priest's assumption that the usual rules of economic relationships do not apply to him and the canon, but that he can get rich quick anyway. Before he is a fool for false science, he is first a fool for false economics.

This nexus of alchemy, economy, and greed is central to the Yeoman's own moralization of his tale:

Considereth, sires, how that, in ech estaat,

Bitwixe men and gold ther is debaat

So ferforth that unnethes is ther noon.

This multiplying blent so many oon

That in good feith I trowe that it bee

The cause grettest of swich scarsetee.

Philosophres speken so mystily

In this craft that men kan nat come therby,

For any wit that men han nowe-a-dayes...

A man may lightly lerne, if he have aught,

To multiplie, and brynge his good to naught!

[VIII.1388-96, 1400-01]

As in Gower, the word "multiplying" signals the convergence of alchemical and economic discourses. ${ }^{92}$ In all estates, Chaucer says, "Bitwixe men and gold ther is debaat," due, obviously, to man's irrational but inevitable greed. So "blent" and deluded, they misunderstand natural processes (as through alchemy) and social processes (like the

${ }^{92}$ See Schmidt, General Prologue, p. 162; W. W. Skeat, ed., The Works of Geoffrey Chaucer, vol. 5 (Oxford: Clarendon, 1900), p. 420. Duncan, “The Literature of Alchemy," sees the term "multiplicacioun" as key to the tale's meaning. 
economic forces of the marketplace). Thus a desire for "multiplying" is paradoxically the cause of "scarsetee.” As Kaye's model suggests, an analytical and practical understanding of the economic world could lead Chaucer to an understanding of the laws and principles governing the natural world. Alchemy, in contrast, is false economics that leads to false chemistry. For Chaucer, alchemy is where pseudo-science meets pseudosocial-science.

What alchemy is not, for Chaucer, is a metaphor for capitalism. It is, to a large extent, its opposite. The forces of a collective market in which each agent pursues individual self-interest - that is, economics — are, if properly observed, rational, explicable, and open to analysis. Alchemy, with its chicanery, self-delusion, and magical thinking, is not.

This is not to say, though, that Chaucer possesses a classical understanding of economics. Classical economists, and to an even greater extent neo-classical economists, see the market as universal, transhistorical, and inevitable, in other words, as natural. But a technological conception of money should lead one to see market economics as an artificial phenomenon — not false, but not natural. It is man-made. Aristotle says as much in the Ethics, where he concedes that money is not natural, but he emphasizes that it is artificial in the sense not that it is a violation of nature but in the sense that it is a man-made convention, which, like other inventions, can be used for the good. The name "money" (nomisma), he notes, derives from nomos, "law," "because it exists not by nature but by law, and it is in our power to change it."93 In the Canon's Yeoman's Tale, market transactions and monetized relationships are not the only possible kinds of human

93 Aristotle, p. 409 
interactions. One can, like the canon, assume that "profred servyce stynketh," and treat others instrumentally in interactions designed for personal profit. Or one can behave like the priest's landlady, who, out of a sense of personal connection, gives the priest his board and ignores his contractual obligation to repay her. Her actions are based not on personal profit, but on the social value of granting exemptions, thereby affirming and extending relationships that are independent of competition and calculation of a market transaction. She treats her interaction with the priest essentially as a gift relationship. The folly of the priest is to think that he can individually profit from the money economy while naively maintaining associations and values from earlier and different systemslike the gift values of his landlady, or the faux-courtly devotion of the canon. Chaucer could learn from the functioning of market economics to apprehend rational and measurable patterns in the natural world. But I also think that he understood that economics describes human behaviors in one particular context, the market and the money economy, a context that was in his time relatively new. It was new enough for Chaucer to know that there are other value systems besides the market, and other choices for rational agents besides individual, competitive self-interest. But society and the self must therefore not be naturally defined by money or market competition. So, while Chaucer's economic imagination is not that of Marx, it is also not that of Adam Smith, and even less that of Friedrich Hayek.

Just as important, Chaucer's economics are not Gower's. Alchemy is for both Chaucer and Gower an essential trope for understanding economics. But whereas Gower idealizes alchemy as a vision of natural increase and pure wealth that is the opposite of the monetized economy, Chaucer reviles alchemy as the obscurantist antithesis of both 
scientific technology and economics, which are logical systems that, while artificial, can only be understood rationally and empirically. 